\title{
Proliferative Activity in Peripheral and Coronary Atherosclerotic Plaque among Patients Undergoing Percutaneous Revascularization
}

\author{
J. Geoffrey Pickering, Lawrence Weir, Jaclynn Jekanowski, Marianne A. Kearney, and Jeffrey M. Isner \\ Departments of Medicine (Cardiology) and Biomedical Research, St. Elizabeth's \\ Hospital, Tufts University School of Medicine, Boston, Massachusetts 02135
}

\begin{abstract}
We evaluated the proliferative activity of human atherosclerotic lesions associated with active symptoms of ischemia, by assessing the expression of the proliferating cell nuclear antigen (PCNA). We confirmed in vitro that PCNA, an essential component of the DNA synthesis machinery, is selectively expressed in proliferating human vascular smooth muscle cells. 37 atherosclerotic lesions (18 primary and 19 restenotic) retrieved by directional atherectomy from either coronary or peripheral arteries were then studied for the expression of PCNA, using in situ hybridization or immunohistochemistry. Among plaques studied by in situ hybridization, 7 out of 11 primary and 11 out of 11 restenotic lesions contained PCNA-positive cells. The mean rate of proliferation (percent of PCNA-positive cells) was $7.2 \pm 10.8 \%$ in primary lesions and $20.6 \pm 18.2 \%$ in restenotic lesions $(P<0.05)$. Among specimens studied by immunohistochemistry, five out of seven primary and eight out of eight restenotic lesions contained proliferating cells. The mean rate of proliferation was again higher in the restenotic $(15.2 \pm 13.6 \%)$ than primary $(3.6 \pm 3.5 \%)$ lesions $(P<0.05)$. Proliferating cells were detected as late as 1 yr after angioplasty. We conclude that cellular proliferation is a feature of atherosclerotic lesions which are associated with symptoms of ischemia, but that it is more prominent in restenosis compared to primary lesions. These findings have implications for therapies aimed at limiting lesion growth, particularly after percutaneous revascularization. (J. Clin. Invest. 1993.91:1469-1480.) Key words: vascular smooth muscle cell $\bullet$ proliferation • proliferating human vascular smooth muscle cells $\bullet$ restenosis • atherectomy
\end{abstract}

\section{Introduction}

Accumulation of smooth muscle cells in the intima of human arteries has been recognized as a central feature of atherosclerosis for more than 30 years $(1,2)$. These cells, which originate either in the intima or underlying media, undergo excessive and abnormally regulated proliferation that directly increases the thickness of the intima and ultimately determines how extensive the plaque will be (3). It is therefore not surprising that

Address correspondence to Jeffrey M. Isner, M.D., St. Elizabeth's Hospital, 736 Cambridge St., Boston, MA 02135.

Received for publication 1 June 1992 and in revised form 21 September 1992.

J. Clin. Invest.

(c) The American Society for Clinical Investigation, Inc.

$0021-9738 / 93 / 04 / 1469 / 12 \$ 2.00$

Volume 91, April 1993, 1469-1480 inhibition of smooth muscle cell proliferation has been investigated as a potential strategy for the treatment of patients with vascular disease (4). This is particularly so for accelerated forms of atherosclerosis, such as restenosis after balloon angioplasty (5), where intimal smooth muscle cells are particularly abundant $(6,7)$.

Effective use of agents designed to inhibit smooth muscle cell proliferation will depend in part on whether such agents can be given at a time when cell replication in the lesion is on-going, and by inference continues to play a role in disease progression. Although the degree and time course of cell proliferation have been well characterized in animal models of vascular disease, information regarding cell proliferation in human lesions is limited. Growth rates of smooth muscle cells cultured from human atherosclerotic lesions have been assessed $(8,9$, 10). Direct information on proliferation rates in vivo, however, is limited to findings in atherosclerotic coronary arteries from hearts removed at the time of cardiac transplantation (11). In most transplant recipients, however, symptoms of heart failure supersede those of myocardial ischemia (12); the very low rates of cellular proliferation observed in these cases may thus reflect a final stage of the atherosclerotic process. The extent to which lesions associated with ongoing ischemic symptoms are comprised of proliferating cells has not been previously established. Knowledge of whether cellular proliferation is still a biologically relevant feature at this stage would not only provide insight into the pathogenesis of disease progression, but might also have important implications for therapy.

The use of percutaneous transluminal atherectomy has provided new opportunities to study atherosclerotic tissue from actively symptomatic patients. In the present study, we sought to determine the degree of cell proliferation in symptom-producing vascular lesions by examining the expression of the proliferating cell nuclear antigen ( $\mathrm{PCNA})^{1}$ in both primary and restenotic atherosclerotic lesions retrieved at the time of percutaneous revascularization by directional atherectomy. PCNA is an essential cofactor for DNA polymerase $\delta(13,14)$, and its presence in the cell is considered to be a specific indication that the cell is replicating $(15,16)$. Since the total amount of PCNA in atherosclerotic fragments could be quite low, we specifically examined PCNA gene expression at the level of the single cell using both in situ hybridization and immunocytochemistry. Using cultured human arterial smooth muscle cells, we first confirmed that both the mRNA for PCNA and the corresponding protein were selectively expressed in proliferating cells. We subsequently analyzed primary and restenotic atherosclerotic tissue from a series of 36 patients who underwent percutaneous atherectomy for symptomatic vascular disease.

1. Abbreviation used in this paper: PCNA, proliferating cell nuclear antigen. 


\section{Methods}

Cell culture. Primary cultures of human vascular smooth muscle cells were used to confirm the reliability of PCNA mRNA and PCNA protein as markers of human smooth muscle cell proliferation. Cells were cultivated by explant outgrowth from the unused portions of internal mammary artery retrieved during coronary artery bypass surgery. The identity of smooth muscle cells was confirmed by their multilayered growth pattern, positive immunostaining for smooth muscle $\alpha$-actin (mAb clone 1A4; Sigma Immunochemicals, St. Louis, MO), and negative immunostaining with mAb to Factor VIII-related antigen (Signet Laboratories, Inc., Dedham, MA). Cells in the first or second subculture were seeded on to multiwell slides and studied in either a quiescent growth state (after incubation for $96 \mathrm{~h}$ in media supplemented with $0.5 \%$ FBS) or in an actively proliferating state (induced by changing to media supplemented with $10 \%$ FBS).

PCNA mRNA and protein expression were evaluated by in situ hybridization and immunocytochemistry, respectively, consistent with the methods used to study the tissue specimens retrieved by directional atherectomy (see below). Cells studied for gene expression by in situ hybridization were fixed by immersion in $4 \%$ paraformaldehyde for 7 min followed by immersion in methanol for $5 \mathrm{~s}$. Cells studied for protein expression by immunocytochemistry were fixed by immersion in methanol/acetone (50:50) at $-20^{\circ} \mathrm{C}$ for $7 \mathrm{~min}$.

To determine the proportion of PCNA-expressing cells that were in the $\mathrm{S}$ phase of the cell cycle, a double labeling approach was used. Actively growing cells were incubated for $4 \mathrm{~h}$ with $\left[{ }^{3} \mathrm{H}\right]$ thymidine $(2.5$ $\mu \mathrm{Ci} / \mathrm{ml}, 6.7 \mathrm{Ci} / \mathrm{mmol}$, New England Nuclear, Boston, MA). Cells were then washed with PBS (pH 7.2), fixed in methanol/acetone and immersed for $20 \mathrm{~min}$ in $10 \%$ trichloroacetic acid. Cells were then immunostained for PCNA as described below. Slides were subsequently dipped in radiographic emulsion (NTB-2; Eastman Kodak, Rochester, $\mathrm{NY}$ ), exposed in the dark for $4 \mathrm{~d}$, developed, and counterstained with hematoxylin.

Vascular tissue. A total of 37 atherosclerotic lesions from 36 patients were studied. Lesions were retrieved percutaneously by therapeutic directional atherectomy using the Simpson AtheroCath from Devices for Vascular Intervention (Redwood City, CA) according to previously described techniques (17). The atherectomy site was determined by a preprocedure angiogram performed immediately before the atherectomy. 18 lesions removed by directional atherectomy were obtained from patients undergoing percutaneous revascularization for the first time; these lesions were designated as primary lesions. Another 19 lesions were identified at the site of a previous percutaneous intervention and were therefore designated as restenosis lesions. 22 lesions ( 11 primary and 11 restenotic) were studied by in situ hybridization. These comprised a consecutive series of lesions stored in liquid nitrogen before study. A further 15 lesions ( 7 primary and 8 restenotic) were studied by immunocytochemistry; these specimens were retrieved from a prospectively studied, consecutive series of patients undergoing directional atherectomy. Among the primary lesions, nine (50\%) were from patients presenting with an acute ischemic syndrome (unstable angina or leg pain at rest). All of the restenotic lesions were from patients presenting with a recurrence of exercise-induced ischemia. The period of time between the initial angioplasty and the subsequent atherectomy ranged from 1.6 to $12.2 \mathrm{mo}$. Clinical data for the 36 patients are summarized in Table $\mathbf{I}$.

In situ hybridization analysis. Atherectomy tissue designated for PCNA mRNA analysis was placed immediately in fresh $4 \%(\mathrm{wt} / \mathrm{vol})$ paraformaldehyde. After $2 \mathrm{~h}$, the tissue was removed from the fixative and immersed in $30 \%$ sucrose for $12-18 \mathrm{~h}$. Samples were then frozen in $\mathrm{OCT}^{\star}$ compound (Miles Laboratories, Elkhart, IN) and stored in liquid nitrogen vapor until sectioning. $7 \mu \mathrm{m}$ cryostat sections were cut on to gelatin- or silane-coated slides and baked overnight at $42^{\circ} \mathrm{C}$. In situ hybridization was performed according to methods described previously (18). Briefly, sections were immersed sequentially in PBS containing $0.1 \mathrm{M}$ glycine for $10 \mathrm{~min}$ and $0.3 \%$ Triton X-100 in PBS for 15 $\mathrm{min}$. They were then treated with proteinase $\mathrm{K}$ in $0.1 \mathrm{M}$ Tris ( $\mathrm{pH} \mathrm{8.0)}$
Table I. Clinical and Demographic Characteristics of Study Subjects

\begin{tabular}{|c|c|c|c|c|c|}
\hline Patient & Age & Lesion type & Lesion site & $\begin{array}{l}\text { Months after } \\
\text { PTA/PTCA }\end{array}$ & $\begin{array}{c}\text { PCNA } \\
\text { detected }\end{array}$ \\
\hline & $y r$ & & & & \\
\hline 1 & 68 & Primary & SFA & - & mRNA \\
\hline 2 & 69 & Primary & SFA & - & mRNA \\
\hline 3 & 40 & Primary & SFA & - & mRNA \\
\hline 4 & 64 & Primary & $\mathrm{AT}$ & - & mRNA \\
\hline 5 & 61 & Primary & Pop & - & mRNA \\
\hline 6 & 59 & Primary & LAD & - & mRNA \\
\hline 7 & 64 & Primary & RCA & - & mRNA \\
\hline 8 & 56 & Primary & LAD & - & mRNA \\
\hline 9 & 56 & Primary & LAD & - & mRNA \\
\hline 10 & 70 & Primary & RCA & - & mRNA \\
\hline 11 & 59 & Primary & LAD & - & mRNA \\
\hline 12 & 74 & Primary & SFA & - & protein \\
\hline 13 & 60 & Primary & SFA & - & protein \\
\hline 14 & 62 & Primary & Pop & - & protein \\
\hline 15 & 61 & Primary & SFA & - & protein \\
\hline 16 & 45 & Primary & SFA & - & protein \\
\hline 17 & 72 & Primary & LAD & - & protein \\
\hline 18 & 59 & Primary & RCA & - & protein \\
\hline 19 & 57 & Restenotic & SFA & 4.5 & mRNA \\
\hline 20 & 68 & Restenotic & SFA & 6.0 & mRNA \\
\hline 21 & 47 & Restenotic & SFA & 7.9 & mRNA \\
\hline 22 & 43 & Restenotic & SFA & 4.0 & mRNA \\
\hline 23 & 80 & Restenotic & SFA & 3.9 & mRNA \\
\hline 24 & 71 & Restenotic & SFA & 8.5 & mRNA \\
\hline 25 & 69 & Restenotic & SFA & 5.0 & mRNA \\
\hline 26 & 45 & Restenotic & RCA & 5.2 & mRNA \\
\hline 27 & 72 & Restenotic & LAD & 1.6 & mRNA \\
\hline 28 & 74 & Restenotic & LAD & 6.1 & mRNA \\
\hline 29 & 65 & Restenotic & RCA & 7.9 & mRNA \\
\hline 30 & 51 & Restenotic & SFA & 9.4 & protein \\
\hline 31 & 65 & Restenotic & SFA & 3.5 & protein \\
\hline 32 & 68 & Restenotic & Iliac & 6.0 & protein \\
\hline 33 & 68 & Restenotic & Iliac & 6.0 & protein \\
\hline 34 & 72 & Restenotic & SFA & 6.3 & protein \\
\hline 35 & 71 & Restenotic & SFA & 5.3 & protein \\
\hline 36 & 78 & Restenotic & SFA & 4.2 & protein \\
\hline 37 & 41 & Restenotic & SFA & 12.2 & protein \\
\hline
\end{tabular}

AT, anterior tibial artery; LAD, left anterior descending coronary artery; Pop, politeal artery; PCNA, proliferating cell nuclear antigen; PTA, percutaneous transluminal angioplasty; PTCA, percutaneous transluminal coronary angioplasty; RCA, right coronary artery; SFA, superficial femoral artery.

with $50 \mathrm{mM}$ EDTA at $37^{\circ} \mathrm{C}$ for 25 minutes. Proteolysis was arrested by immersion in $4 \%$ paraformaldehyde. Slides were immersed in $0.25 \%$ acetic anhydride in $0.1 \mathrm{M}$ triethanolamine, then prehybridized in $50 \%$ formamide and $2 \times \operatorname{SSC}(1 \times \operatorname{SSC}=0.15 \mathrm{M}$ sodium chloride, $0.015 \mathrm{M}$ sodium citrate). For hybridization $10 \mu \mathrm{l}$ of hybridization buffer containing $3 \times 10^{5} \mathrm{cpm}$ of ${ }^{35} \mathrm{~S}$-labeled antisense RNA probes was applied to each slide. Covered slides were incubated at $42^{\circ} \mathrm{C}$ for $16 \mathrm{~h}$. Samples were washed for $1 \mathrm{~h}$ in $4 \times \mathrm{SSC}$ at $37^{\circ} \mathrm{C}$ and treated with ribonuclease $\mathrm{A}$ $(20 \mu \mathrm{g} / \mathrm{ml}$, Sigma Immunochemicals) for $30 \mathrm{~min}$ to degrade unhybridized probe. They were then washed successively in $2 \times$ SSC and $0.1 \times$ SSC, and then dehydrated in a graded series of alcohols containing 
$0.3 \%$ ammonium acetate. Air-dried slides were coated with Kodak NTB-2 emulsion, exposed for $10 \mathrm{~d}$ at $4^{\circ} \mathrm{C}$, and then developed. To rule out false positive results, ${ }^{35} \mathrm{~S}$-labeled sense RNA probes for PCNA were used on the same series of slides under identical conditions.

The PCNA RNA probe used was transcribed from a 1,400 bp cDNA fragment of human PCNA subcloned into pGEM4. This was a kind gift from Dr. R. Baserga, (Temple University, PA). The probes were synthesized with either T7 or SP6 polymerases to generate antisense or sense probes, respectively.

Immunocytochemistry. The presence of PCNA protein was evaluated in cultured smooth muscle cells and tissue sections using a mouse mAb to human PCNA (Signet Laboratories Inc.) (19, 20). Immunoreactivity to PCNA has varied considerably depending on tissue fixation and the particular antibody used $(19,21)$. We used sections of human tonsil to optimize the immunostaining procedure. Detection of PCNA on cryostat sections prefixed in paraformaldehyde proved to be unsatisfactory with weak staining that was not well localized to cell nuclei. This precluded studying PCNA protein expression on identical or adjacent sections to those used for PCNA mRNA analysis. In contrast, immunostaining of paraffin-embedded sections fixed in alcohol-based preservatives (methanol, absolute alcohol, and methyl Carnoy's solution) showed intense nuclear staining of cells that were primarily localized to the germinal centers (Fig. 1). All tissue designated for PCNA protein analysis was therefore fixed by immersion in $100 \%$ methanol overnight. Paraffin-embedded sections were cut on to poly-L-lysinecoated slides and air dried overnight. Endogenous peroxidase activity was blocked with $3.0 \%$ hydrogen peroxide in PBS. Sections were pretreated with $10 \%$ horse serum and then incubated with anti-PCNA antibody ( $1: 50$ dilution) overnight at $4^{\circ} \mathrm{C}$. Bound primary antibody was detected using an avidin-biotin-immunoperoxidase method ac- cording to the supplier's guidelines (Signet Laboratories Inc.). Sections were lightly counterstained with either methyl green or Gill's hematoxylin.

Cell types within the plaque were determined using monoclonal antibodies specific to either smooth muscle $\alpha$ actin (clone 1A4; Sigma Immunochemicals) or macrophages (HAM56; Enzo Diagnostics Inc., New York)

Analysis. Histologic analysis was performed without knowledge of the clinical data. All cells in a given section were counted and the total number was expressed relative to the total tissue area. This was determined by planimetry of the microscopic image (Bausch and Lomb Inc., Rochester, NY) projected on to a digitizing palette (Summagraphics, Fairfield, CT) that was interfaced with a MacIntosh computer. Medial tissue adjacent to plaque was excluded if present. For tissues studied by in situ hybridization the number of exposed silver grains overlying a given nucleus was counted under high power microscopy. The number of silver grains thus served as an index of the copy number of PCNA mRNA molecules. Using the nuclear borders to define a region for counting provided a convenient means of semi-quantifying gene expression in frozen sections, where cell borders are poorly defined. Approximately 80-100 cells (mean 87 ) from randomly selected high power fields were studied for each tissue and the mean expression (exposed silver grains per nuclear area) was determined. The number of positive cells per tissue section was also determined, based on a threshold value for positivity. This was derived from the number of silver grains per nucleus of cells in the media of normal internal mammary artery. Cells in normal arterial tissue have a very low (0-0.096\%) rate of replication $(22,23)$, and a very low likelihood of expressing PCNA protein detectable by immunohistochemistry $(0-0.3 \%)(11)$. Therefore, as an internal reference for each in situ hybridization proce-

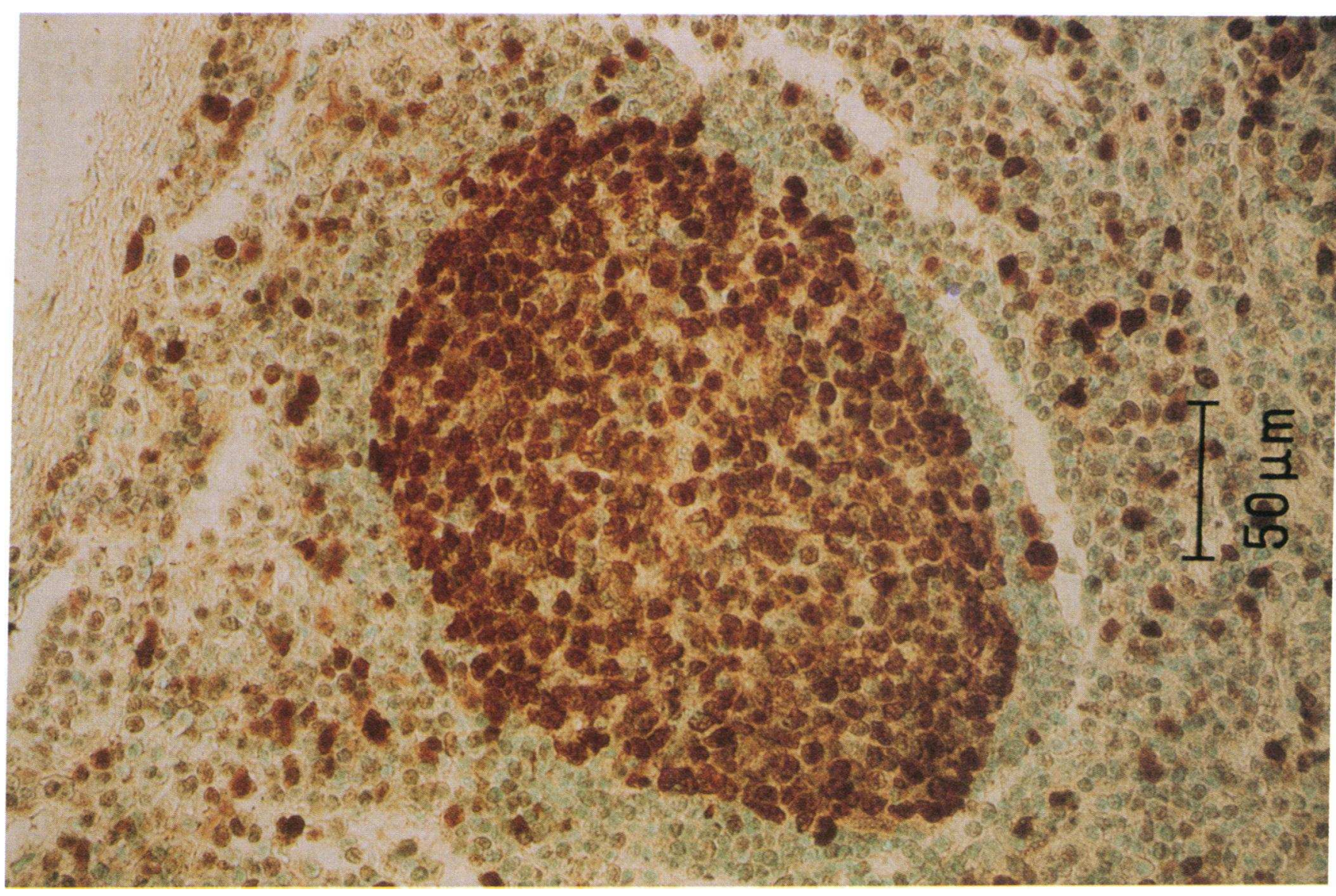

Figure 1. Light photomicrograph of a section of human tonsil immunostained with anti-PCNA antibody. Cells in the germinal center are strongly positive. Scattered interfollicular cells are also positive. (Methyl green.) 
dure, we included a section from a single internal mammary artery. In this control tissue the overall number of grains per nuclear area was normally distributed, ranging from 0 to 6 . A cell was considered positive, therefore, if the grain count exceeded the mean count for the normal artery by three times the standard deviation. This cut point was between 10 and 15 grains per counting area. To determine the reproducibility of the method used to analyze the specimens studied by in situ hybridization, 11 of the 22 lesions were reanalyzed after an interval of several weeks; in each of the 11 cases, no significant deviation from the initial assessment was observed.

For sections studied by immunocytochemistry, the proportion of PCNA-positive cells was determined and all intimal cells within the section were counted. This varied from 80 to 1,843 intimal cells per tissue section. Sections were reviewed by at least two observers.

Statistics. Averaged data are expressed as mean \pm SD of the mean. Student's $t$ test, one-way ANOVA, and linear regression analysis were used for statistical analyses.

\section{Results}

PCNA expression in quiescent and proliferating cultured human vascular smooth muscle cells. To confirm that the presence of PCNA mRNA reliably distinguishes proliferating from nonproliferating human smooth muscle cells, we assessed mRNA abundance in cells incubated in the presence of nonstimulating $(0.5 \%)$ or stimulating $(10 \%)$ concentrations of FBS. In situ hybridization was used for this assessment to maintain consistency with the approach taken to study mRNA expression in the atherectomy material. Fig. 2 illustrates the difference in hybridization between the proliferating and nonproliferating cells. Results from two experiments demonstrated a fivefold increase in the number of exposed silver grains overlying nuclei, after quiescent cells were induced to proliferate. The high expression of PCNA mRNA was present in virtually all of the cells grown in the media supplemented with $10 \%$ serum.

The presence of PCNA protein detectable by immunocytochemistry was also dependent on the proliferative status of the cells. Quiescent cells were negative for PCNA; however, $48 \mathrm{~h}$ after stimulation with $10 \%$ serum, $\sim 90 \%$ of the cells stained positively (Fig. 3, $A$ and $B$ ). Staining was localized to the nuclei with the exception of cells in mitosis or in cells that had apparently just divided (Fig. 3, $C$ and $D$ ).

Expression of PCNA in serum-stimulated cells was observed in almost all cells whether or not they had been previously synchronized (by serum deprivation), implying that the presence of PCNA is not specific to the $S$ phase of the cell cycle. This was examined further by simultaneously assessing both PCNA immunoreactivity and incorporation of $\left[{ }^{3} \mathrm{H}\right]-$ thymidine. Of 552 cells counted, $96 \%$ were PCNA positive but only $14 \%$ had incorporated $\left[{ }^{3} \mathrm{H}\right]$ thymidine into the nucleus. All thymidine-positive cells were immunopositive for PCNA. These findings are illustrated in Fig. $3 E$.

Cell density of human atherosclerotic lesions. The mean cell density of the intima of primary plaque tissue was $241 \pm 179$ cells $/ \mathrm{mm}^{2}$ (range, $46-674$ cells $/ \mathrm{mm}^{2}$ ). There was no difference between the cell density of lesions from coronary and peripheral arteries ( $206 \pm 68$ vs $269 \pm 235$ cells $/ \mathrm{mm}^{2}, P=\mathrm{NS}$ ). The cell density of the intimal portion of restenotic lesions was significantly higher than that of primary lesions $(500 \pm 238$ cells $/ \mathrm{mm}^{2}$, range $181-1,007$ cells $/ \mathrm{mm}^{2}, P<0.001$ ). Again, there was no difference in cell density between the lesions from coronary vs peripheral arteries $(688 \pm 257$ vs $450 \pm 215$ cells/ $\left.\mathrm{mm}^{2}, P=\mathrm{NS}\right)$.
Cell proliferation in human atherosclerotic lesions. Media from seven internal mammary artery tissues, including one used as an internal standard for each in situ hybridization procedure, were used to ascertain PCNA mRNA and protein expression in the nonatherosclerotic vessel wall. In none of the tissues was there evidence for PCNA expression. Among the five tissues studied by in situ hybridization, only a background level of radiographic granules was present with a mean of $3.1 \pm 1.1$ silver grains per cell nucleus (range 1.9-4.6 silver grains per cell nuclear area).

PCNA expression in the primary atherosclerotic lesions was variable. Of the 11 specimens studied by in situ hybridization, the mean nuclear grain density $(4.9 \pm 3.8$ silver grains $/$ nuclear area) was not significantly greater than that of the internal mammary artery sections, although the range (1.4-13.6 silver grains/nuclear area) was wider. Furthermore, in 7 of the 11 lesions, positive hybridization signals were present over a proportion of cells. The mean proportion of positive cells in a given lesion was $7.2 \pm 10.8 \%$ (range $0-32.8 \%$ ). Positive cells were seen both in isolation and as clusters (Fig. 4). PCNA-positive cells were also identified by immunocytochemistry in five of the seven primary lesions studied with this approach; the mean proportion of immunopositive cells was $3.6 \pm 3.5 \%$ ( range $0-8.5 \%$ ). The proportion of positive cells was not different between coronary or peripheral artery lesions $(4.4 \pm 7.9$ vs $6.9 \pm 9.6 \%, P=$ NS). There was also no evident relationship between the age of the patient and the proportion of proliferating cells.

Restenotic atherosclerotic lesions consistently showed cellular expression of PCNA (Figs. 5 and 6). Among those studied by in situ hybridization, the mean nuclear grain density was $8.9 \pm 5.5$ (range 3.8-59.2), significantly higher than that of normal artery sections $(P<0.05)$. This also tended to be higher than that of primary tissue, although this was not statistically significant. The mean proportion of PCNA-positive cells was $20.6 \pm 18.2 \%$ (range $4.0-59.2 \%$ ) for sections studied by in situ hybridization and $15.2 \pm 13.6 \%$ (range $2.0-37.1 \%$ ) for those studied with the anti-PCNA antibody. In both instances, there was a higher prevalence of positive cells than in the primary lesions studied by the same approach $(P<0.05)$ (Fig. 7$)$. The proportion of PCNA-positive cells among both primary and restenotic lesions tended to be higher in the tissues studied by in situ hybridization; however, this was not statistically significant. As with the primary lesions, the proportion of positive cells was not significantly different between coronary and peripheral artery lesions $(12.0 \pm 6.9$ vs $20.0 \pm 17.7 \%, P=N S)$. Again, there was also no detectable correlation between the proportion of proliferating cells and the age of the patient.

Among restenotic lesions, there was a tendency toward a higher degree of proliferation in tissue excised relatively early postangioplasty (Fig. 8); however, no statistically significant correlation between PCNA-positivity and the time interval from angioplasty to subsequent atherectomy could be demonstrated. Interestingly, the atherectomy specimen that was temporally most distant from the initial angioplasty (patient number 37 ) demonstrated a relatively high proportion (33.3\%) of PCNA-immunopositive cells.

As illustrated in Fig. 6, a distinct majority of the cells in both primary and restenotic lesions were smooth muscle cells. A smaller proportion of cells either stained positively with the macrophage-specific antibody or were negative for both markers. The proportion of cells identified as macrophages was 

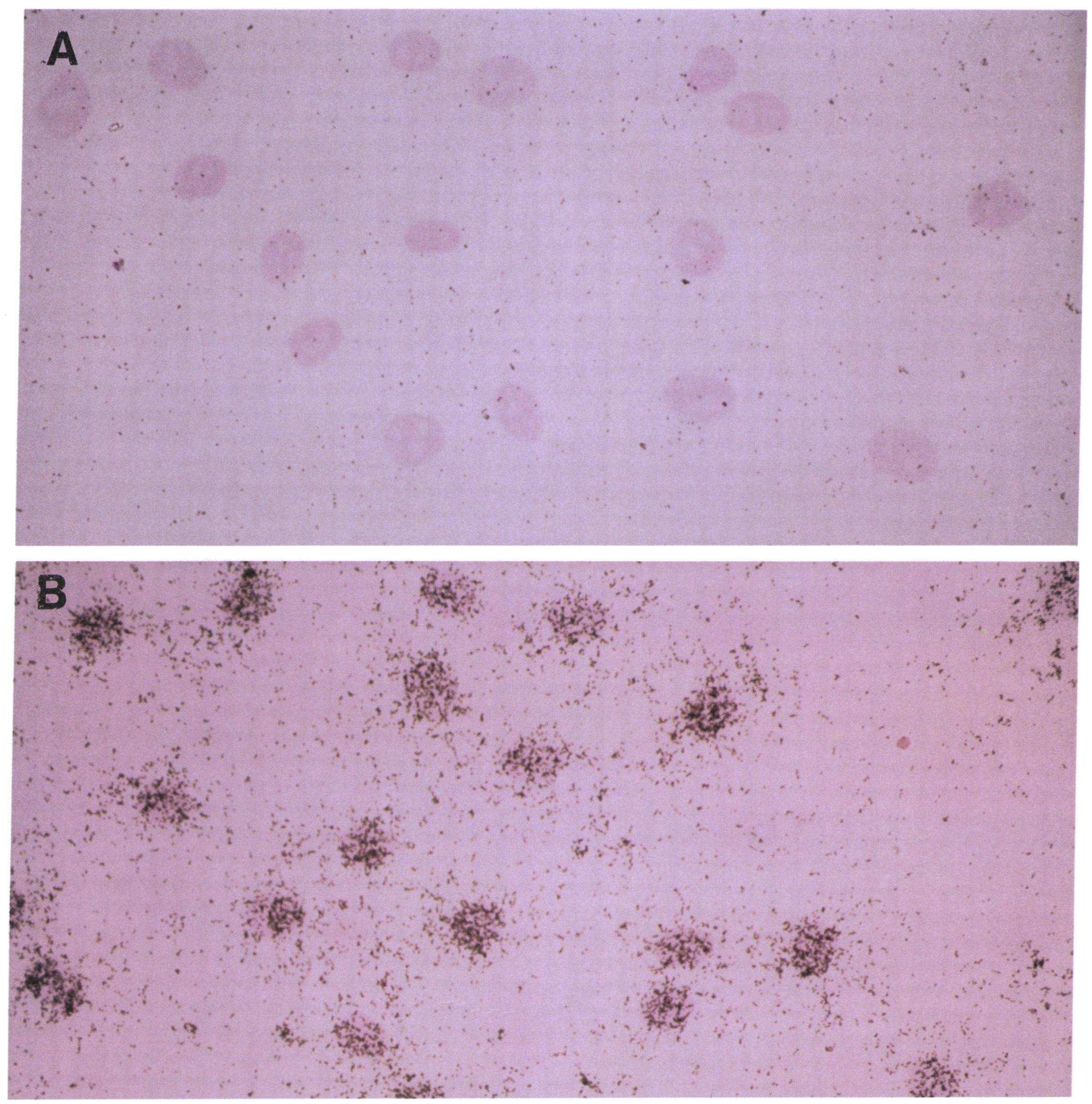

Figure 2. Autoradiographs showing hybridization signals from cultured human vascular smooth muscle cells hybridized with an antisense RNA probe to PCNA. $(A)$ Cells were rendered quiescent by incubating in serum-depleted medium for $88 \mathrm{~h}$. Exposed silver grains are present only as background signals. $(B)$ Cells were restimulated to grow by addition of serum. Dense collections of silver grains overlie all nuclei. (Hematoxylin.)

higher in primary lesions than in restenotic lesions $(12.7 \pm 5.9$ vs $1.4 \pm 2.4 \%, P<0.01)$. Among all tissues there was a positive correlation between the proportion of PCNA-positive cells and the overall cell density $(r=0.52, P<0.001)$. Data from all lesions studied are summarized in Table II.

\section{Discussion}

The accumulation of cells within the intima has been recognized as a fundamental feature of atherosclerotic lesions for many years (1-3). More recently, the widespread application of percutaneous balloon angioplasty has focused attention upon the clinical consequences of excess proliferation of intimal cells: light microscopic analyses have suggested that smooth muscle cell proliferation is the principal basis for recurrent symptoms (caused by restenosis) seen in $>30 \%$ of patients after angioplasty $(6,7,24-26)$. Accordingly, a variety of strategies have been proposed and/or investigated to prevent or retard the proliferation of intimal smooth muscle cells (5). The appropriateness and effectiveness of this approach, how- 

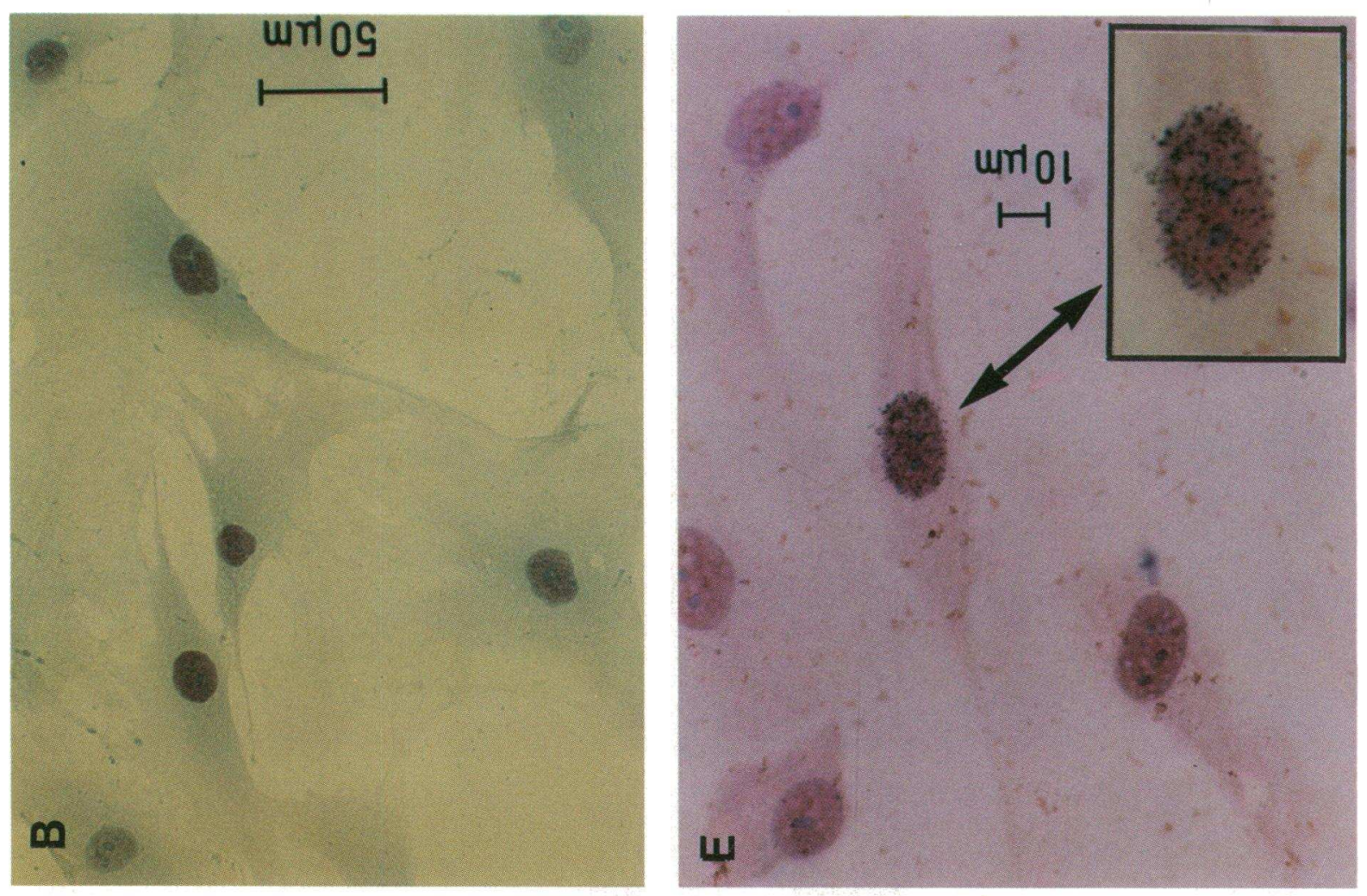

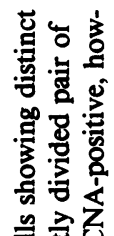

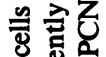

远

号家

县悉

ㄴ.

볼

品 응 匈志告

我综

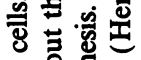

苛

क 彭资 ชิ (1) 石 8 . 突

范

乙。

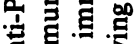
而家 s

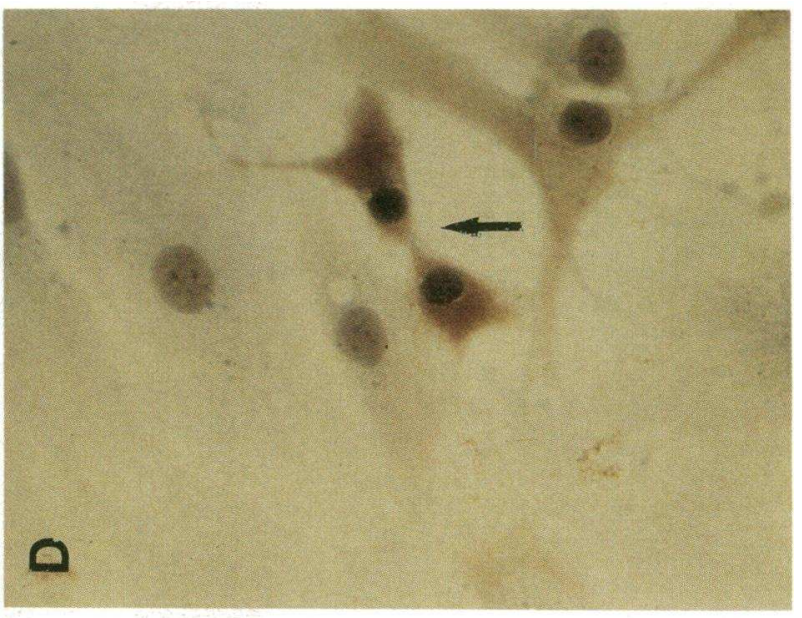

记

छ녕

氜

苞若 影

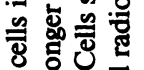
능 혈 5 ํㅕㅇ 웅 배을 क 仓 卷㐘可 㽞 要学 震

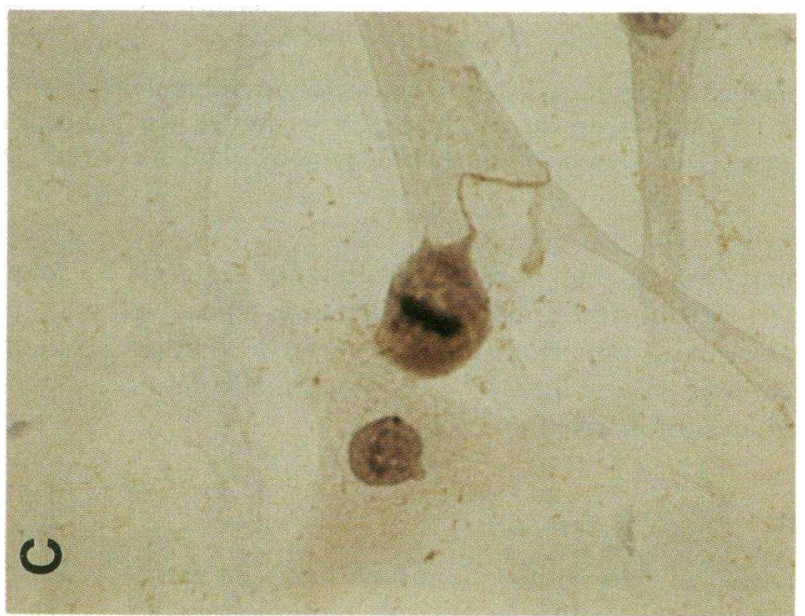

ह 행영 렬 อ 응 s.

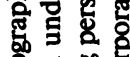
율 응 . 数 은흘 잉 핵을 

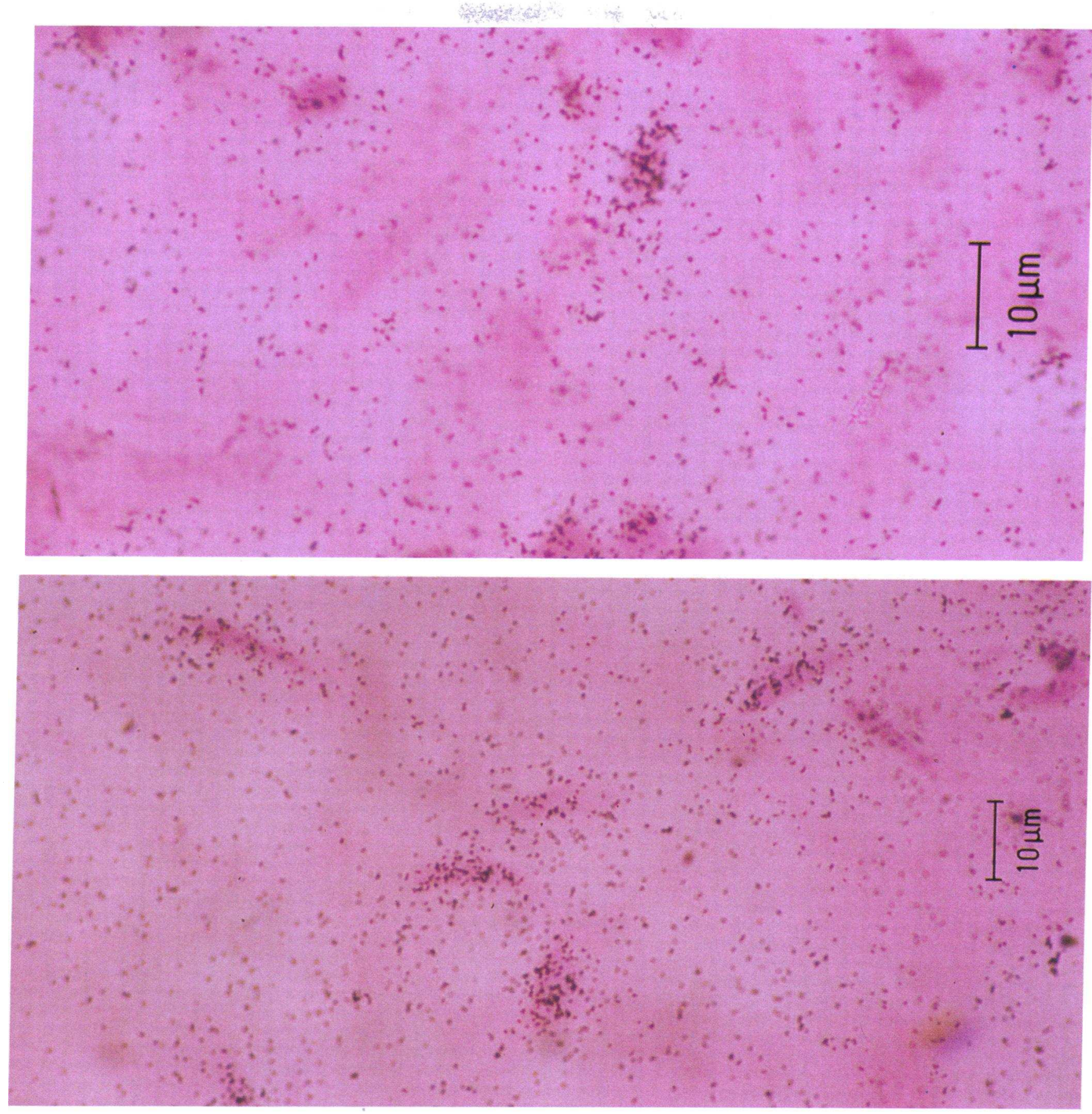

Figure 4 (Top). Autoradiograph of a section of primary atherosclerotic lesion hybridized with an antisense RNA probe to PCNA. Positive signals overlie a cluster of cells. (Hematoxylin and eosin.)

Figure 5 (Bottom). Autoradiograph of a section of a restenotic lesion hybridized with an antisense RNA probe to PCNA. Clusters of signals overlie several cells. (Hematoxylin and eosin).

ever, may depend upon the extent to which cell proliferation persists at the time therapy would be considered. The degree of cell proliferation in atherosclerotic lesions associated with ongoing symptoms of ischemia is therefore a fundamental question that has previously not been directly studied. Examination of PCNA expression in atherectomy specimens obtained from the 36 patients in the present study indicates that active cell proliferation is a variable feature of symptom-producing lesions that have not been previously subjected to percutaneous revascularization ("primary lesions"). In lesions that have recurred after balloon angioplasty ("restenosis lesions") however, cell proliferation is a consistent and relatively prominent feature which may be detected as late as $1 \mathrm{yr}$ after revascularization.

PCNA is a highly conserved nuclear protein of molecular weight $36,000(15,27)$. It has been identified as a cofactor of DNA polymerase $\delta(13,14)$ and is necessary for the cell to enter and proceed through $S$ phase of the replication cycle 

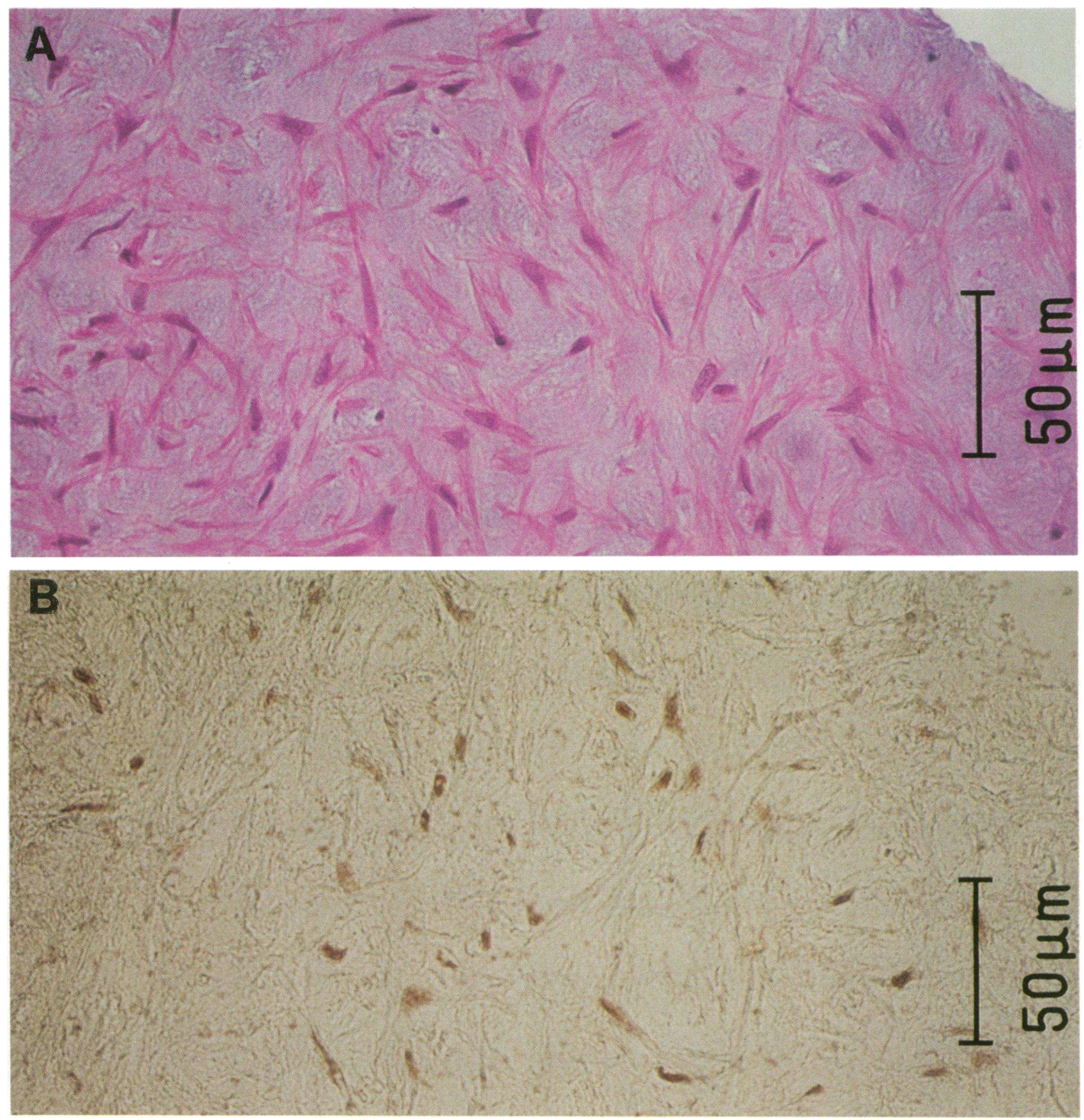

Figure 6. Light photomicrographs of adjacent sections of a restenotic lesion. $(A)$ Hematoxylin- and eosin-stained section illustrating hypercellularity. $(B)$ Section immunostained with anti-PCNA antibody. A high proportion of nuclei are positive. (Methyl green.) $(C)$ Section immunostained with antibody to smooth muscle $\alpha$-actin. Vascular smooth muscle cells predominate. (Hematoxylin.)

(28). Marked differences in the levels of PCNA have been consistently observed between proliferating cells and noncycling, quiescent cells. Specifically, expression of both PCNA mRNA and protein have been shown to increase severalfold after cells rendered quiescent by serum starvation have been induced to proliferate $(15,29-31)$. Because of this differential expression, immunodetection of PCNA has recently been used to directly determine the proliferative state of the cells in tissue sections $(19,21,32,33)$, thereby circumventing the need to place the excised tissue in an ex vivo growth environment.

To thoroughly evaluate PCNA gene expression in vascular tissue and reliably exploit its presence as a marker for smooth muscle cell proliferation, we assessed the abundance of both PCNA mRNA and PCNA protein. In situ hybridization was used to assess mRNA content, since this approach allows for assessment of individual cells and is thus suitable for studying the small tissue fragments retrieved by the atherectomy device. The yield of mRNA from such samples is too low (generally $<5 \mu \mathrm{g}$ of total RNA) for a comprehensive Northern blot analysis. Using human vascular smooth muscle cells in culture we confirmed that quiescent and proliferating cells could be clearly distinguished by the abundance of PCNA mRNA, as 


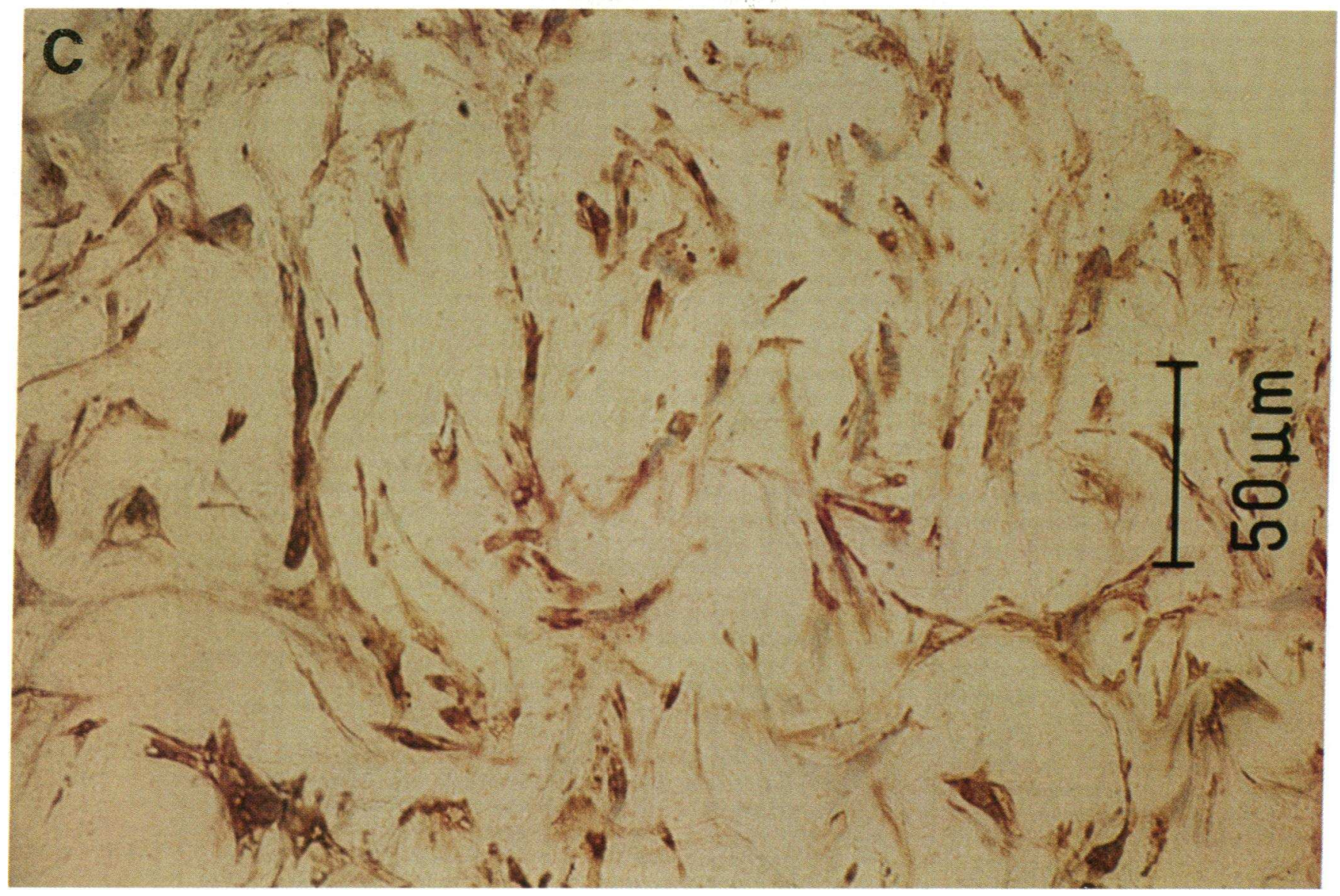

Figure 6 (Continued)

evaluated specifically by in situ hybridization. Likewise, these populations of cells were easily discriminated by immunostaining with the mAb to PCNA. The fact that nearly all cells stimulated to grow, including those undergoing mitosis, were positive for PCNA mRNA or protein suggests that the presence of PCNA is not specific to a single phase of the cell cycle. In fact, using a double labelling technique, we established that of all PCNA-positive cells only a small fraction $(<15 \%)$ were in S phase during the $4 \mathrm{~h}$ before fixation and immunostaining. This is consistent with findings of previous studies of nonvascular cells or tissue that compared immunoreactivity of PCNA with either DNA synthesis (11) or flow cytometry (33) data. To-

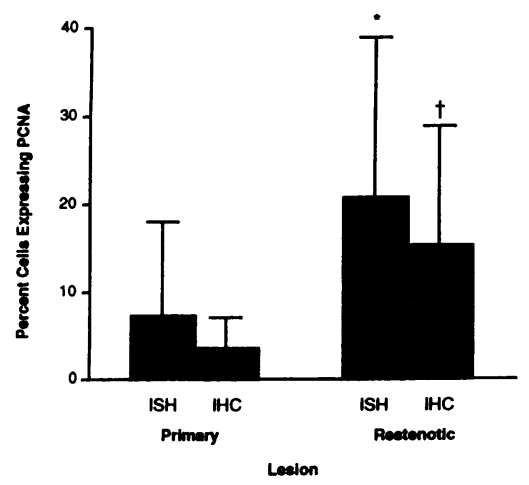

Figure 7. Proportion of cells expressing PCNA in primary and restenotic plaque. $I S H$, in situ hybridization. IHC, immunohistochemistry. ${ }^{*} P<0.05$ vs the primary lesions studied by in situ hybridization; ${ }^{\dagger} P<0.05$ vs the primary lesions studied by immunohistochemistry. gether, these data support the concept that expression of PCNA is detectable in all proliferating (cycling) cells, but not in resting, or $\mathrm{G}_{0}$ phase cells. In this context it is a sensitive marker for smooth muscle cell proliferation per se. The proportion of cells in atherosclerotic plaque that are specifically in S phase, would, by extrapolation of the in vitro analysis, be considerably lower.

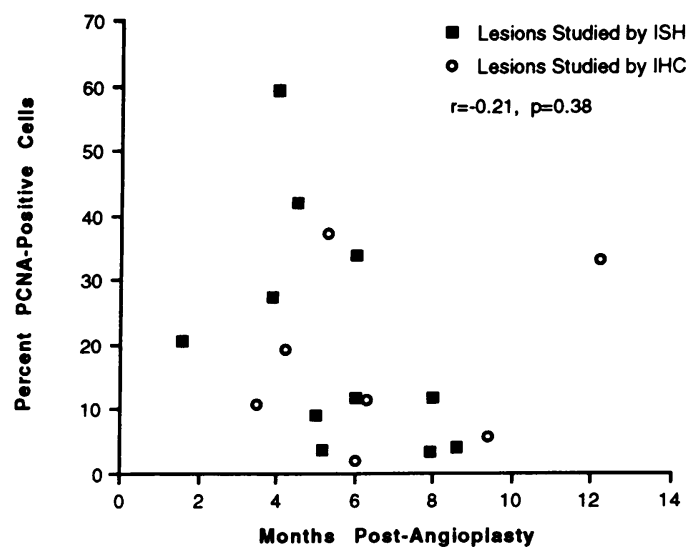

Figure 8. Relation between percent of cells expressing PCNA in restenotic tissue and interval between angioplasty and subsequent atherectomy. Solid squares denote lesions studied by in situ hybridization. Open circles denote lesions studied by immunohistochemistry. 
Table II. Cell Number and Cell Proliferation in Atherectomy Specimens

\begin{tabular}{|c|c|c|c|c|c|}
\hline Patient & Lesion type & $\begin{array}{l}\text { Total cells/total } \\
\text { specimen area }\end{array}$ & Cells $/ \mathrm{mm}^{2}$ & $\begin{array}{l}\text { PCNA-positive } \\
\text { cells }\end{array}$ & Percentage \\
\hline & & $\mathrm{mm}^{2}$ & & & \\
\hline \multicolumn{6}{|l|}{ ISH } \\
\hline 1 & Primary peripheral & $586 / 0.869$ & 674 & $27 / 82$ & 32.9 \\
\hline 2 & Primary peripheral & $65 / 0.510$ & 127 & $5 / 65$ & 7.7 \\
\hline 3 & Primary peripheral & $262 / 1.589$ & 165 & $5 / 69$ & 7.2 \\
\hline 4 & Primary peripheral & $192 / 1.324$ & 145 & $0 / 94$ & 0 \\
\hline 5 & Primary peripheral & $505 / 0.758$ & 666 & $2 / 110$ & 3.6 \\
\hline 6 & Primary coronary & $510 / 2.601$ & 196 & $4 / 97$ & 4.1 \\
\hline 7 & Primary coronary & $712 / 2.220$ & 321 & $0 / 82$ & 0 \\
\hline 8 & Primary coronary & $450 / 1.869$ & 241 & $19 / 83$ & 22.9 \\
\hline 9 & Primary coronary & $329 / 1.713$ & 192 & $0 / 86$ & 0 \\
\hline 10 & Primary coronary & $51 / 0.622$ & 82 & $0 / 51$ & 0 \\
\hline 11 & Primary coronary & $182 / 0.882$ & 204 & $1 / 92$ & 1.1 \\
\hline 19 & Restenotic peripheral & $551 / 0.622$ & 885 & $42 / 100$ & 42.0 \\
\hline 20 & Restenotic peripheral & $2953 / 4.427$ & 667 & $40 / 118$ & 33.9 \\
\hline 21 & Restenotic peripheral & $2123 / 3.694$ & 575 & $4 / 118$ & 3.4 \\
\hline 22 & Restenotic peripheral & $1745 / 2.176$ & 802 & $48 / 81$ & 59.2 \\
\hline 23 & Restenotic peripheral & $2021 / 3.960$ & 510 & $23 / 84$ & 27.4 \\
\hline 24 & Restenotic peripheral & $1762 / 4.165$ & 423 & $6 / 67$ & 9.0 \\
\hline 25 & Restenotic peripheral & $960 / 2.340$ & 410 & $4 / 100$ & 4.0 \\
\hline 26 & Restenotic coronary & $573 / 1.120$ & 512 & $3 / 80$ & 3.8 \\
\hline 27 & Restenotic coronary & $181 / 0.420$ & 430 & $17 / 82$ & 20.7 \\
\hline 28 & Restenotic coronary & $1121 / 1.315$ & 852 & $9 / 77$ & 11.7 \\
\hline 29 & Restenotic coronary & $1119 / 1.167$ & 959 & $12 / 102$ & 11.8 \\
\hline \multicolumn{6}{|l|}{ IHC } \\
\hline 12 & Primary peripheral & $461 / 2.070$ & 223 & $7 / 461$ & 1.5 \\
\hline 13 & Primary peripheral & $354 / 0.841$ & 420 & $30 / 354$ & 8.5 \\
\hline 14 & Primary peripheral & $118 / 0.843$ & 140 & $7 / 118$ & 5.9 \\
\hline 15 & Primary peripheral & $326 / 4.126$ & 79 & $7 / 326$ & 2.1 \\
\hline 16 & Primary peripheral & $80 / 1.753$ & 46 & $0 / 80$ & 0 \\
\hline 17 & Primary coronary & $169 / 0.701$ & 241 & $0 / 169$ & 0 \\
\hline 18 & Primary coronary & $127 / 0.754$ & 168 & $9 / 127$ & 7.1 \\
\hline 30 & Restenotic peripheral & $449 / 0.828$ & 542 & $26 / 449$ & 5.8 \\
\hline 31 & Restenotic peripheral & $1056 / 2.500$ & 422 & $40 / 373$ & 10.7 \\
\hline 32 & Restenotic peripheral & $293 / 1.619$ & 181 & $6 / 293$ & 2.0 \\
\hline 33 & Restenotic peripheral & $333 / 1.802$ & 185 & $7 / 333$ & 2.1 \\
\hline 34 & Restenotic peripheral & $325 / 1.003$ & 325 & $56 / 325$ & 11.4 \\
\hline 35 & Restenotic peripheral & $1843 / 7.500$ & 246 & $684 / 1843$ & 37.1 \\
\hline 36 & Restenotic peripheral & $992 / 3.971$ & 250 & $191 / 992$ & 19.2 \\
\hline 37 & Restenotic peripheral & $998 / 3.039$ & 328 & $333 / 998$ & 33.3 \\
\hline
\end{tabular}

ISH, lesions studied for PCNA expression by in situ hybridization; IHC, lesions studied by immunohistochemistry.

The observation that immunoreactivity was localized to the germinal centers and scattered interfollicular cells of methanolfixed sections of human tonsil confirmed that immunohistochemistry was a valid means of assessing PCNA protein content for the purpose of this study. The immunohistochemical approach also allows for comparison with results of previous studies ( see below). The results of in situ hybridization, on the other hand, yield different, and in this case, confirmatory data using an independent approach. We and others (19) have observed that use of frozen sections (optimal for in situ hybridization ) results in a substandard quality of immunostaining with the anti-PCNA mAb used; we chose, therefore, to use separate tissues, with different fixation procedures, for the two modes of analysis. Nevertheless, the results suggest that the degree of positivity for in situ hybridization was generally similar to that observed by immunohistochemistry.

Gordon and co-workers have previously used anti-PCNA immunostaining to quantify proliferation in the coronary arteries of hearts explanted from patients undergoing cardiac transplantation (11). In that patient population, some atherosclerotic lesions ( 3 out of 14) displayed no evidence of proliferation, and the overall proportion of PCNA-positive cells was relatively low ( mean $0.85 \%$ ). In contrast, among actively symptomatic patients in the current study, the fraction of PCNApositive cells in primary lesions studied by immunohistochemistry appeared higher (mean $3.6 \%$ ). Among primary lesions 
studied by in situ hybridization, the proportion of PCNA-positive cells was also higher (mean $7.2 \%$ ) including two lesions in which $>20 \%$ of cells expressed detectable levels of PCNA. This difference could reflect differences either in the nature of the lesions studied, or in technical aspects of the methods used to detect PCNA. In particular, differences in section preparation and fixation, as well as differences in the epitope recognized by the different mAb may be relevant. These considerations notwithstanding, it is conceivable that the typically advanced nature of atherosclerotic lesions from patients with end-stage cardiac disease undergoing cardiac transplantation are more quiescent than atherosclerotic lesions in patients with active symptoms of myocardial ischemia. The data presented here suggest that in patients referred for percutaneous revascularization, some lesions may be indolent, but many have a detectable proliferative component.

In primary or spontaneous atherosclerosis, the progression of early lesions to more extensive plaques that manifest as exertional angina or claudication proceeds at a variable rate (34). Angiographic (35, 36), angioscopic (37), and pathologic (38) findings suggest that instances of particularly rapid plaque growth may be initiated by recurrent fissuring of the plaque with consequent formation of small, subocclusive thrombi that subsequently organize into fibrotic tissue. The finding in the present study of certain primary plaques with numerous (e.g., $>10 \%$ ) proliferating cells suggests that rapid growth of some primary atherosclerotic lesions may also involve an increased wave of smooth muscle cell proliferation. The trigger for such an increase in cell replication is not clear, but the process is likely mediated through the expression of growth regulatory factors (39). In this regard, these two potential mechanisms of plaque enlargement are not necessarily independent, since platelets in mural thrombi have the potential to release growth factors that stimulate smooth muscle cell proliferation (40). It is noteworthy, therefore, that of the primary lesions examined in the present study, $50 \%$ were from patients in whom an acute ischemic syndrome represented the indication for atherectomy. There is good evidence to indicate that unstable ischemic syndromes in both coronary (34) and peripheral (41) arteries may be precipitated by rupture of the atherosclerotic plaque. Thus, the relatively high incidence of cellular proliferation observed among the primary lesions in the current series of patients may be related to mitogenesis initiated by plaque rupture.

More rapid accumulation of intimal smooth muscle cells is considered to be the principal mechanism of lesion recurrence (restenosis) after balloon angioplasty or other catheter-based vascular interventions $(4,6,7)$. Quantification of cells in atherosclerotic plaques examined in the current study confirms that restenotic plaque is, on average, more cellular than primary plaque. Most of the cells were identified as smooth muscle cells by immunohistochemistry. This hypercellularity may be accounted for either by increased proliferation of cells within the intima, and/or migration into the intima of smooth muscle cells originating in the underlying arterial media (42). The relative contribution of each of these processes was not addressed in the present study. Nevertheless, the consistent expression of PCNA in the restenotic lesions constitutes the first direct evidence for ongoing cellular proliferation within human restenotic plaque. In some restenotic lesions, the proportion of proliferating cells approximated that of human solid tumors $(33,43)$. These higher proliferation rates tended to be among lesions retrieved relatively early after the initial angioplasty, although a significant correlation between PCNA positivity and the period of time between angioplasty and the subsequent atherectomy was not established. A larger series may characterize this relationship more definitively.

Dartsch and co-workers have previously demonstrated that the in vitro growth rate of smooth muscle cells derived from restenotic plaque was greater than that of cells derived from primary lesions (9). Similarly, we have previously found that the kinetics of smooth muscle cell outgrowth from human athrectomy specimens, distinguishes restenotic from primary lesions (10). Although these ex vivo approaches do not allow for a determination of replication rates in vivo, the findings are consistent with the direct, quantitative results of the present study.

From the perspective of designing treatment strategies for patients with coronary or peripheral vascular disease, restenosis represents a unique circumstance where the time frame for lesion development is relatively short and well defined. The finding that proliferating cells still constitute a significant proportion of the lesion once it has progressed to induce symptoms, even after several months, indicates that the opportunity to limit the process may not necessarily be confined to a small "window" immediately after revascularization. This is an encouraging result that supports the concept that inhibiting the proliferation of vascular smooth muscle cells may be a valid means of limiting or preventing restenosis.

\section{Acknowledgments}

We wish to thank Dr. D. Gordon, University of Michigan (Ann Arbor, MI) for reviewing with us the slide material described in this manuscript and for his many helpful comments.

This work was supported in part by grants from the National Heart, Lung, and Blood Institute ( HL-40518 and HL-02824-01 to J. M. Isner, AR40580 to L. Weir), and the John and Cora Davis Foundation (Washington, D.C.) J. G. Pickering is a Research Fellow of the Medical Research Council of Canada.

\section{References}

1. Haust, M., R. More, and H. Movat. 1960. The role of smooth muscle cells in the fibrogenesis of arteriosclerosis. Am. J. Pathol. 37:377-389.

2. Benditt, E. P., and J. M. Benditt. 1973. Evidence for a monoclonal origin of the human atherosclerotic plaques. Proc. Natl. Acad. Sci. USA. 70:1753-1756.

3. Ross, R. 1986. The pathogenesis of atherosclerosis: an update. New Engl. J. Med. 314:488-500.

4. Ip, J., V. Fuster, L. Badimon, J. Badimon, M. B. Taubman, and J. H. Chesebro. 1990. Syndromes of accelerated atherosclerosis: role of vascular injury and smooth muscle cell proliferation. J. Am. Coll. Cardiol. 15:1667-1687.

5. Hermans, W., B. Rensing, B. Strauss, and P. Serruys. 1991. Prevention of restenosis after percutaneous transluminal coronary angioplasty: the search for a "magic bullet." Am. Heart. J. 122:171-187.

6. Garratt, K. N., W. D. Edwards, U. P. Kaufmann, R. E. Vleistra, and D. R. Holmes. 1991. Differential histopathology of primary atherosclerotic and restenotic lesions in coronary arteries and saphenous vein grafts: analysis of tissue obtained from 73 patients by directional atherectomy. J. Am. Coll. Cardiol. 17:442-448.

7. Nobuyoshi, M., T. Kimura, H. Ohishi, H. Horiuchi, H. Nosaka, N. Hamasaki, H. Yokoi, and K. Kim. 1991. Restenosis after percutaneous transluminal coronary angioplasty: pathologic observations in 20 patients. J. Am. Coll. Cardiol. 17:433-439.

8. Ross, R., T. N. Wight, E. Strandness, and B. Theile. 1984. Human atherosclerosis I. Cell constitution and characteristics of advanced lesions of the superficial femoral artery. Am. J. Pathol. 114:79-93.

9. Dartsch, P. C., R. Voisard, G. Bauriedel, B. Hofling, and E. Betz. 1990. Growth characteristics and cytoskeletal organization of cultured smooth muscle cells from human primary stenosing and restenosing lesions. Arteriosclerosis. 10:62-75. 
10. Pickering, J. G., L. Weir, K. Rosenfield, J. Stetz, J. Jekanowski, and J. M. Isner. 1992. Smooth muscle cell outgrowth from human atherosclerotic plaque: implications for the assessment of lesion biology. J. Am. Coll. Cardiol. 20:1430 1439.

11. Gordon, D., M. Reidy, E. Benditt, and S. Schwartz. 1990. Cell proliferation in human coronary arteries. Proc. Natl. Acad. Sci. USA. 87:4600-4604. 224

12. Copeland, J. 1988. Cardiac transplantation. Curr. Prob. Cardiol. 13:157-

13. Bravo, R., R. Frank, P. Blundell and H. MacDonald-Bravo. 1987. Cyclin/ PCNA is the auxiliary protein of DNA polymerase-delta. Nature (Lond.) 326:515-517.

14. Prelich, G., C.-K. Tan, M. Kostura, M. Mathews, A. So, K. Downey, and B. Stillman. 1987. Functional identity of proliferating cell nuclear antigen and a DNA polymerase-delta auxiliary protein. Nature (Lond.). 326:517-520.

15. Bravo, R., and J. Celis. 1980. A search for differential polypeptide synthesis throughout the cell cycle of HeLa cells. J. Cell Biol. 84:795-802.

16. Bravo, R. 1986. Synthesis of the nuclear protein cyclin (PCNA) and its relationships with DNA replication. Exp. Cell. Res. 163:287-293.

17. Johnson, D. E., T. Hinihara, M. R. Selmon, L. J. Braden, and J. B. Simpson. 1990. Primary peripheral artery stenoses and restenoses excised by transluminal atherectomy: a histopathologic study. J. Am. Coll. Cardiol. 15:419425 .

18. Leclerc, G., J. Isner, M. Kearney, M. Simons, R. Safian, D. Baim, and L. Weir. 1992. Evidence implicating nonmuscle myosin in restenosis: use of in situ hybridization to analyze human vascular lesions obtained by directional atherectomy. Circulation. 85:543-553.

19. Hall, P., D. Levison, A. Woods, C.-W. Yu, D. Kellock, J. Watkins, D. Barnes, C. Gillet, R. Camplejohn, N. Waseem, and D. Lane. 1990. Proliferating cell nuclear antigen (PCNA) immunolocalization in paraffin sections: an index of cell proliferation with evidence of deregulated expression in some neoplasms. J. Pathol. 162:285-294.

20. Waseem, N., and D. Lane. 1990. Monoclonal antibody analysis of the proliferating cell nuclear antigen (PCNA). Structural conservation and the detection of a nucleolar form. J. Cell Sci. 96:121-129.

21. Galand, P., and C. Degraef. 1989. Cyclin/PCNA immunostaining as an alternative to tritiated thymidine pulse labelling for marking $S$ phase cells in paraffin sections from animal and human tissues. Cell Tissue Kinet. 22:383-392.

22. Spagnoli, L., S. Villaschi, L. Neri, G. Palmiera, M. Taurino, V. Faraglia and P. Fiorani. 1981. Autoradiographic studies of the smooth muscle cells in human arteries. Artery Wall. 7:107-112.

23. Villaschi, S., and L. Spagnoli. 1983. Autoradiographic and ultrastructural studies on the human fibro-atheromatous plaque. Atherosclerosis. 48:95-100.

24. Ueda, M., A. E. Becker, T. Tsukada, F. Numano, and T. Fojimoto. 1991. Fibrocellular tissue response after percutaneous transluminal coronary angioplasty. Circulation. 83:1327-1332.

25. Holmes, D. R., R. E. Vliestra, H. C. Smith, G. W. Vetrovec, K. M. Kent, M. J. Cowley, D. P. Faxon, A. R. Gruntzig, S. F. Kelsey, H. M. Detre, et al. 1984 Restenosis after percutaneous coronary angioplasty (PTCA): a report from the PTCA registry from the National Heart Lung and Bloon Institute. Am. J. Cardiol. 53:77C-81C.

26. Serruys, P. W., H. E. Luijten, K. J. Beat, R. Geuskens, P. J. de Feyter, M. van den Brand, J. H. C. Reiber, H. J. ten Katen, G. A. van Es, and P. G. Hugenholtz. 1988. Incidence of restenosis after successful coronary angioplasty: a timerelated phenomenon. A quantitative angiographic study in 42 consecutive patients at 1, 2, 3, and 4 months. Circulation. 77:361-371.
27. Suzuka, I., H. Daidoji, M. Matsuoka, K. Kadowaki, T. Yoshinari, P. Nakane, and T. Moriuchi. 1989. Gene for proliferating cell nuclear antigen (DNA polymerase delta auxiliary protein) is present in both mammalian and higher plant genomes. Proc. Natl. Acad. Sci. USA. 86:3183-3193.

28. Jaskulski, D., J. DeRiel, E. Mercer, B. Calabretta, and R. Baserga. 1988. Inhibition of cellular proliferation by antisense oligodeoxynucleotides to PCNA cyclin. Science (Wash. DC). 240:1544-1546.

29. Bravo, R., and H. Macdonald-Bravo. 1987. Existence of two populations of cyclin/proliferating cell nuclear antigen during the cell cycle: association with DNA replication sites. J. Cell Biol. 105:1549-1554.

30. Almendral, J., D. Huebsch, P. Blundell, H. Macdonald-Bravo, and R. Bravo. 1987. Cloning and sequence of the human nuclear protein cyclin: homology with the DNA binding proteins. Proc. Natl. Acad. Sci. USA. 84:1575-1579.

31. Jaskulski, D., C. Gatti, S. Travali, B. Calabretta, and R. Baserga. 1988. Regulation of the proliferating cell nuclear antigen cyclin and thymidine kinase mRNA levels by growth factors. J. Biol. Chem. 263:10175-10179.

32. Kawakita, N., S. Seki, S. Sakaguchi, A. Yanai, T. Kuroki, Y. Mizoguchi, K. Kobayashi, and T. Monna. 1992. Analysis of proliferating hepatocytes using a monoclonal antibody against proliferating cell nuclear antigen/cyclin in embedded tissues from various liver diseases fixed in formaldehyde. Am. J. Pathol. 140:513-520.

33. Garcia, R., M. Coltrera, and A. Gown. 1989. Analysis of proliferative grade using anti-PCNA/cyclin monoclonal antibodies in fixed, embedded tissues. Comparison with flow cytometric analysis. Am. J. Pathol. 134:733-739.

34. Fuster, V., L. Badimon, J. Badiman, and J. H. Chesebro. 1992. The pathogenesis of coronary artery disease and the acute coronary syndromes. (First of two parts). N. Engl. J. Med. 326:242-250.

35. Levin, D., and J. Fallon 1982. Significance of the angiographic morphology of localized coronary stenosis: histopathologic correlations. Circulation. 66:316-320.

36. Ambrose, J., S. Winters, A. Stern, A. Eng, L. Teichholz, R. Gorlin, and V. Fuster. 1985. Angiographic morphology and the pathogenesis of unstable angina pectoris. J. Am. Coll. Cardiol. 5:609-616.

37. Sherman, C., F. Litvack, W. Grundfest, M. Lee, A. Hickey, A. Chaux, R. Kass, C. Blanche, J. Matloff, L. Morgenstern, et al. 1986. Coronary angioscopy in patients with unstable angina pectoris. $N$. Engl. J. Med. 315:913-919.

38. Richardson, P., M. Davies, and G. Born. 1989. Influence of plaque config uration and stress distribution on fissuring of coronary atherosclerotic plaques. Lancet. 2:941-944.

39. Ross, R., J. Masuda, and E. Raines. 1990. Cellular interactions, growth factors, and smooth muscle cell proliferation in atherogenesis. Ann. NY Acad. Sci. 598:102-112.

40. Ross, R., J. Glomset, B. Kariya, and L. Harker. 1974. A platelet-dependent serum factor that stimulates the proliferation of arterial smooth muscle cells in vitro. Proc. Natl. Acad. Sci. USA. 71:1207-1210.

41. Mecley, M., K. Rosenfield, and J. M. Isner. 1992. Crescendo claudication. Ann. Int. Med. 117:663-666.

42. Hanke, H., T. Strohschneider, M. Oberhoff, E. Betz, and K. R. Karsch. 1990. Time course of smooth muscle cell proliferation in the intima and media of arteries following experimental angioplasty. Circ. Res. 67:651-659.

43. Kamel, O., W. Franklin, J. Ringus, and J. Meters. 1989. Thymidine labelling index and Ki67 growth fractions in lesion of the breast. Am. J. Pathol. 134:107-113. 